FACTA UNIVERSITATIS

Series: Working and Living Environmental Protection Vol. 18, № 2, 2021, pp. 69 - 77

https://doi.org/10.22190/FUWLEP2102069B

Original Scientific Paper

\title{
A METHODOLOGICAL FRAMEWORK FOR RESEARCH OF ERGONOMIC RISK FACTORS IN DENTISTRY
}

\author{
UDC 331.101.1:616.31
}

\author{
Bojan Bijelić1, Miroljub Grozdanović², Evica Stojiljković ${ }^{3}$ \\ ${ }^{1,3}$ University of Niš, Faculty of Occupational Safety, Niš, Serbia \\ ${ }^{2}$ Engineering Academy of Serbia, Department of Electrical and Computer Engineering, \\ Belgrade, Serbia
}

\begin{abstract}
This paper proposes a methodological framework for the research of ergonomic risk factors in dentistry, since this is a profession with very specific and complex ergonomic challenges. When analyzing ergonomic risk factors in dental practice, three separate entities should be taken into account: the dentist, as the central figure in the office; the dental office equipment, which includes all the instruments and devices, dental chair and dentist stool; and the dental office, including the workplace layout and the working conditions. Bearing in mind that it is impossible to eliminate the risk, systematic analysis of ergonomic risk factors enabled us to propose solutions for its reduction. Risk reduction improves dentists' work ability and working conditions in the dental office and contributes to a more humane, i.e., more functional design of dental equipment.
\end{abstract}

Key words: ergonomic risk factors, methodological framework, dentist, dental office

\section{INTRODUCTION}

Dentistry is a profession with very specific and complex ergonomic challenges. To achieve adequate working conditions in a dental office, it is necessary to consider all its elements. From the ergonomic point of view, the elements in a dental office can be divided into several important units: the devices, instruments, and appliances used in the dental office, the working conditions that prevail in the dental office, and the dentist himself.

Ergonomic research conducted in dentistry often focuses on understanding the physical and organizational aspects of ergonomics, while the cognitive aspect is usually completely neglected. The cognitive aspect of ergonomics includes the analysis of the human factor, i.e.,

Received October 5, 2021 / Accepted October 11, 2021

Corresponding author: Bojan Bijelić

University of Niš, Faculty of Occupational Safety, Čarnojevića 10a, 18000 Niš, Serbia

E-mail: bojan.bijelic@znrfak.ni.ac.rs

(C) 2021 by University of Niš, Serbia | Creative Commons Licence: CC BY-NC-ND 
human reliability. In fact, in medicine and dentistry, complications in the treatment of patients are most often analyzed from a purely technical point of view, without considering possible human errors [1].

The application of ergonomic principles in dentistry can be viewed as an attempt to adjust the relationship between dentists, dental equipment, and the working environment of the dental office [2]. Achieving harmonized relations between these entities reduces the load on the musculoskeletal system of dentists, which significantly reduces the number of musculoskeletal disorders caused by work as well as their severity. The application of ergonomic principles in dentistry is extremely important given the numerous risk factors. The role of ergonomics is so much more than just the prevention of musculoskeletal disorders caused by work, since the proper application of ergonomic principles increases productivity, improves the general health and job satisfaction of dentists, and extends dentists' careers [3].

Dentists are at higher risk of developing work-related musculoskeletal disorders when compared to the general population [4]. It is almost certain that the vast majority of dentists will experience a problem with their musculoskeletal system during their working life. The first signs of work-related musculoskeletal disorders are often experienced by dentists very early in their career, even during their education [5]. Work-related musculoskeletal disorders have significant social and economic consequences, as they often lead to changes in occupation, a significant reduction in working hours, reduced productivity, or even early retirement $[6,7]$.

Ergonomic risk factors that lead to the development of work-related musculoskeletal disorders can be divided into personal, biomechanical, psychosocial, and organizational risk factors [8]. The nature of the risk factors to which dentists are exposed during their work can be characterized as multifactorial, with the greatest role played by biomechanical and psychosocial factors [6].

Technological progress and numerous innovations have brought many improvements in all branches of medicine, including dentistry. It would be expected that these improvements should solve the numerous ergonomic problems that dentist encounter daily. However, there is extensive evidence that the incidence of work-related musculoskeletal disorders in dentistry remains high. Therefore, this paper aims to form an adequate analytic-synthetic methodological framework for the analysis of ergonomic risk factors in dentistry.

\section{Methodology}

When analyzing ergonomic risk factors in dental practice, three separate entities can be defined, closely related to each other. The first is the dentist, as the central figure in the office, the second is the dental office equipment, which includes all the equipment, instruments, and devices necessary for the work of the dentist, and the third unit is the dental office, which includes the dental office layout and the working conditions that prevail in the dental office. To obtain a complete overview of the ergonomic risk factors in a dental office, these three entities must be thoroughly analyzed and examined. An analyticsynthetic model for research of ergonomic risk factors in dentistry is presented in Figure 1. 


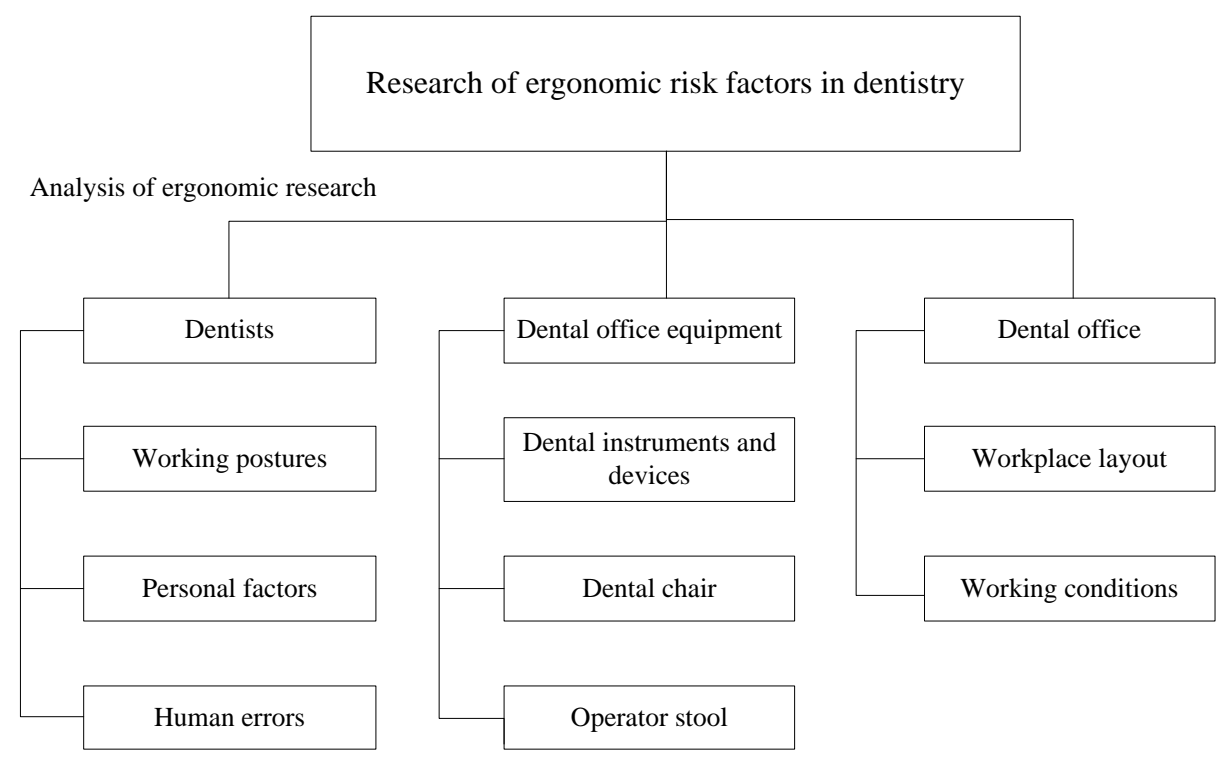

Syntesis of ergonomic research

Improving the working ability of dentists

More humane/
functional design of
equipment in the dental
office
office

$$
\begin{aligned}
& \text { Improving the working } \\
& \text { conditions in dental } \\
& \text { office }
\end{aligned}
$$

Fig. 1 Analytic-synthetic model for research of ergonomic risk factors in dentistry

\section{MAIN ERGONOMIC RISK FACTORS IN DENTISTRY}

\subsection{Dentist}

Several important factors need to be considered regarding the dentist, the most important of which are working postures, personal factors that include the lifestyle, age, life habits, and health of the individual, and human errors that can occur during work.

\subsubsection{Working postures in dentistry}

Working postures are essentially conditioned by the way the dentist works. The two basic ways of working in a dental office are the work of a dentist with the assistance of a dental assistant and the independent work of a dentist. The dental assistant takes over all the tasks related to the preparation of the dental office and materials; he/she gives the materials and instruments to the dentist, while the dentist focuses only on the intervention. Independent work is characterized by a larger number of dentist's movements compared to the work of a dental assistant because the dentist must prepare the patient, materials, and instruments needed for the intervention, as well as bring them to the work area - the patient's mouth. Moreover, the way dentists work and their working postures are closely related and conditioned. Namely, the way of working itself has an extremely important 
influence in terms of ergonomics because it significantly affects the working postures in which the dentist's body is during the intervention. These two factors are often considered the most important for the development of work-related musculoskeletal disorders in dentists.

Working with a patient in a dental chair gives two options to the dentist, as he can either work in a sitting or a standing posture. According to the existing scientific data, the best solution is to combine work in a standing posture with a sitting posture [9]. In such cases working in a sitting posture should take up most of the working day. However, the practice is for the dentists to apply the way they learned at school. It has been observed that older dentists practice a standing posture and find it difficult to switch to a sitting posture, while young dentists mostly work in a sitting posture, as they were taught in dental school.

When working, regardless of the body posture, it is important to respect the ergonomic principles of work, i.e., it is important to take natural body postures so that the load on the musculoskeletal system is reduced to a minimum. Modern dental ergonomics trends suggest that four-hand $(\mathrm{FH})$ dentistry is the most ergonomically convenient way of working [10, 11]. FH dentistry involves the joint work of a dentist and a dental assistant, where the role of the dental assistant is to eliminate unnecessary movements of the dentist by bringing the instruments and material to the operating field (the patient's mouth). On the one hand, this mode of work reduces dentist fatigue during the working day by eliminating unnecessary movements, while on the other hand, it additionally exposes the dentist to work in a static posture. Although this is one of the best ways to work, looking at the work practices of dentists in Serbia, it was determined that it is not so common.

\subsubsection{Personal factors}

Personal factors that affect the state of the musculoskeletal system are age, gender, lifestyle, sports, body weight, diet, consumption of cigarettes, alcohol, and the like [1214]. Work-related musculoskeletal disorders are more frequent in older dentists, as musculoskeletal disorders increase with age. The dentist's musculoskeletal system is often under much stress during the workday, so sufficient rest time must be provided. Failure to provide adequate rest after work has a negative impact and can cause a significant increase in musculoskeletal disorder risk level.

Individual lifestyle has a significant influence on musculoskeletal health. If an individual leads an overly active lifestyle, he additionally burdens his musculoskeletal system, while on the other hand, a sedentary lifestyle is also a risk factor for musculoskeletal health. A moderately active lifestyle would be an adequate choice for a healthy musculoskeletal system. Physical activity or playing sports as part of a lifestyle directly impacts the musculoskeletal system. Moderate physical activity has several positive effects on the musculoskeletal system; however, too much physical activity, as well as certain sports such as extreme sports, have a very negative impact on the musculoskeletal system. An adequate, well-balanced diet and maintaining the optimal body weight reduce the risk of musculoskeletal disorders [15]. On the other hand, obesity has a very negative impact on the occurrence of musculoskeletal problems [16]. In addition, the consumption of cigarettes, alcohol, and unhealthy foods harms the musculoskeletal system and thus increases the risk of musculoskeletal disorders $[17,18]$.

The general state of health is very important in regards to the risk of developing a musculoskeletal disorder. Some health conditions, such as hormonal disorders, thyroid problems, congenital musculoskeletal deformities, diabetes, etc., have a negative impact on the development of work-related musculoskeletal disorders [19, 20]. 


\subsubsection{Human errors}

The human factor often has a great influence on the complications that can occur during dental interventions. However, when analyzing these complications, the human factor is often neglected, and thus the opportunity to obtain the right conclusions about the causes that led to the complications is missed. Some of the most common causes of human errors in dentistry are poor communication between office staff, lack of resources, stress, lack of teamwork, self-confidence, lack of knowledge, fatigue [21].

Neglecting the significance of human error in dentistry brings significant consequences. By analyzing human errors and drawing conclusions about their causes, the number of new errors can be significantly reduced and thus improve patient safety [22]. Human errors in dentistry are made not only by dentists with less experience but also happen to experienced dentists. It is very important to recognize human errors, analyze them and take appropriate measures to prevent them and/or reduce their consequences. To reduce the impact of human errors in dentistry, it is necessary to reduce the probability of human error and reduce the severity of their consequences.

One of the first steps is to raise awareness among dentists about human error and the importance of reporting these errors. If data on a large number of human errors were collected, the processing of these data could lead to adequate conclusions about the causes of human errors in dentistry. This would make it easier to choose the right strategies in the fight to reduce them.

\subsection{Dental office equipment}

The equipment used in the dental office is one of the main sources of ergonomic risk factors for the dentist. The basic elements of the dental office that are of special importance from the ergonomic point of view are dental instruments, dental chairs, and dentist stools.

\subsubsection{Dental instruments and devices}

Dental instruments are the basic tool of every dentist and are used intensively during work. They can significantly affect the ergonomics of the dentist's work due to their construction and design. Most dental instruments are hand-operated, with the dentist performing very precise operations in a small space - the patient's mouth. The dentist makes contact with most of the instruments through the fingers, with several instruments producing specific high-frequency vibrations. It is very important to match the dimensions of the instruments with the dentist's anthropometrical characteristics. Proper maintenance of dental instruments is extremely important and contributes to less dentist fatigue.

One of the modern trends in dentistry is the use of various visual aids to provide better visibility at the workplace. Dentists have at their disposal several visual aids that can significantly help them in their work and improve ergonomics [23]. The most common visual aids used in dentistry are magnifying glasses, dental microscopes, and dental cameras. By providing better visibility with these aids, awkward postures during work can be eliminated, thus reducing stress on the dentist's musculoskeletal system [24].

\subsubsection{Dental chair}

The dental chair is one of the central parts of the office that has a dominant influence on the ergonomics of the dentist's work. A comparison of old and modern dental chairs 
shows a significant difference in terms of ergonomic fit. Namely, the progress of technology has led to the development of dental chairs that are increasingly ergonomically adapted to the dentist. One of the most significant changes, which has been introduced, is the possibility of placing the chair in a lying position, which enabled the work of dentists in a sitting posture with the application of the principle of FH dentistry.

\subsubsection{Dentist stool}

The dentist uses dentist stool to sit during the intervention. The first use of dentist stools and the application of the FH dentistry principle in dentistry dates back to the 1960s. The role of the dentist stool is to provide adequate support to the dentist during work. Various types of dentist stool are used in modern dentistry. Some of them have a general application in other branches of medicine, while others are developed specifically for work in the dental office. Dentist stools used in dental offices differ in the shape of the seat and the backrests they have. The seat part of the dentist stool can be flat, in the shape of a saddle, or as a squat chair. Dental stools can have a backrest, and special armrests used to support the dentist's arm while working with patients. The benefits of using a dentist's stool are scientifically proven and recommended by most dental associations. However, in Serbia, most dentists still work in a standing posture.

\subsection{Dental office}

The dental office is the main workspace in which dentists perform their activities when working with patients. How the office itself is organized is very important from the ergonomic point of view. Two factors related to the dental office with the greatest influence on the ergonomics are the office layout and the working conditions.

\subsubsection{Dental office layout}

Proper layout of the elements in the dental office is very important to eliminate unnecessary movements of the dentist and increase his productivity [25]. The dental practice organization plays a significant role in achieving ergonomic compliance between the dentist and the dental office. The dental chair occupies a central place in every dental office, so it is necessary to distribute all the necessary equipment properly. Equipment layout should be performed following four basic ergonomic principles: the principle of importance according to which the most important parts of the equipment are positioned in optimal locations; frequency of use principle, according to which the equipment most often used is placed close to the user; the principle of function, where the grouping of equipment is done according to their function; and the sequence of use principle, stating that equipment should be arranged by the order in which they are used.

\subsubsection{Working conditions}

Working conditions include physical conditions of the work environment and other aspects of work. Other aspects of work are related to work organization, such as work hours, rest periods, work schedules, work pace, etc. Physical conditions in the work environment itself present a significant ergonomic risk factor. Within the working environment of a dental office, it is necessary to consider thermal comfort, workplace illumination, noise, and vibrations. Thermal comfort at a workplace is affected by environmental factors (air 
temperature, radiant temperature, humidity, and air velocity) and personal factors (clothing and metabolic heat). Inadequate thermal comfort leads to discomfort, which increases the likelihood of musculoskeletal disorders [26]. Proper illumination in the dental office is of great importance when it comes to ergonomics. Localized lighting of the work field - the patient's mouth is especially important. Due to poor illumination, dentists must take awkward postures to see only the workplace better. Noise and vibrations in the dental office originate from the dental instruments and are almost inevitable. Modern instruments produce less noise than older ones, but the noise is still present and negatively affects the work of dentists, mostly due to increased irritability [27]. Although research shows that noise exposure does not pose a significant risk to dentists, hearing loss can occur in older dentists [28]. In addition to noise, most instruments expose the dentist to specific high-frequency vibrations. Symptoms of vibration-induced disorders in the fingers and upper extremities are common in dentists due to the use of devices that produce ultra-vibrations [29].

\section{CONCLUSION}

Solving the ergonomic-related issues that are present in dental practice requires a multidisciplinary approach. It is very difficult to eliminate the most ergonomic risks, so managing them is often the only available solution. Through the process of ergonomic risk management in dentistry, it is necessary to achieve three goals - to improve the working ability of the dentist, to provide more humane, i.e., more functional design of equipment used in the dental office, and improve working conditions in the office. Improving the work ability of dentists is achieved by applying ergonomically acceptable working postures, eliminating personal factors that have a negative impact, and increasing human reliability. The more humane design of the equipment used by the dentist significantly improves the work in terms of ergonomics. When handling equipment that is designed by ergonomic principles, i.e., more humane/functional, the dentist is exposed to a much lower load. Optimization of working conditions implies the organization of the dental office following ergonomic principles in terms of equipment layout and working environment conditions such as temperature, lighting, noise, and vibration.

Ergonomic compliance of key elements in the dental office guarantees that optimal conditions for work will be archived; thus, dentists can work with minimal negative consequences. In this way, the quality of work and life of the dentist can be significantly improved. As a very complex topic due to the synergistic effect of ergonomic risk factors and the human factor, the issue of ergonomic risk requires the application of a comprehensive analytical-synthetic model for research.

Acknowledgement The authors would like to express gratitude to the Ministry of Education, Science and Technological Development of the Republic of Serbia for financial support to this research (contract no. 451-03-9/2021-14/200148). 


\section{REFERENCES}

1. Renouard, F., Amalberti, R., \& Renouard, E. (2017). Are" Human Factors" the Primary Cause of Complications in the Field of Implant Dentistry?. International Journal of Oral \& Maxillofacial Implants, 32(2), pp. 55-61.

2. Iordache, C., Fătu, A. M., Chirieac, R., \& Ancuța, C. (2016). Work-related hand pathology among dentists: A pilot study. International journal of biology and biomedical engineering, 9(10), pp. 225-228.

3. Gupta, A., Bhat, M., Mohammed, T., Bansal, N., \& Gupta, G. (2014). Ergonomics in dentistry. International journal of clinical pediatric dentistry, 7(1), pp. 30-34.

4. Ohlendorf, D., Naser, A., Haas, Y., Haenel, J., Fraeulin, L., Holzgreve, F., Erbe, C., Betz, W., Wanke, E., Brueggmann, D., Nienhaus, A., \& Groneberg, D. A. (2020). Prevalence of Musculoskeletal Disorders among Dentists and Dental Students in Germany. International Journal of Environmental Research and Public Health, 17(23), 8740.

5. Hayes, M. J., Smith, D. R., \& Taylor, J. A. (2014). Musculoskeletal disorders in a 3 year longitudinal cohort of dental hygiene students. American Dental Hygienists' Association, 88(1), 36-41.

6. Gupta, A., Ankola, A. V., \& Hebbal, M. (2013). Optimizing human factors in dentistry. Dental research journal, 10(2), 254.

7. Ng, A., Hayes, M. J., \& Polster, A. (2016, March). Musculoskeletal disorders and working posture among dental and oral health students. Healthcare, 4(1):13.

8. Roquelaure, Y., Garlantézec, R., Evanoff, B. A., Descatha, A., Fassier, J. B., \& Bodin, J. (2020). Personal, biomechanical, psychosocial, and organizational risk factors for carpal tunnel syndrome: a structural equation modeling approach. Pain, 161(4), pp. 749-757.

9. Pejčić, N., Đurić-Jovičić, M., Miljković, N., Popović, D. B., \& Petrović, V. (2016). Posture in dentists: Sitting vs. standing positions during dentistry work: An EMG study. Srpski arhiv za celokupno lekarstvo, 144(3-4), pp. 181-187.

10. Singh, N., Jain, A., Sinha, N., Chauhan, A., Rehman, R. (2014). Application of Four-Handed Dentistry in Clinical Practice: A Review. Journal of International Dental and Medical Research. 1(1), pp. 8-13.

11. Sachdeva, A., Bhateja, S., \& Arora, G. (2020). Ergonomics in dentistry: A comprehensive review. Journal of Dental Research and Review, 7(1), pp. 32-35.

12. Tirgar, A., Khallaghi, S., \& Taghipour, M. (2013). A study on musculoskeletal disorders and personal and occupational risk factors among surgeons. Iranian Journal of Health Sciences, 1(1), pp. 50-57.

13. Nawrocka, A., Niestrój-Jaworska, M., Mynarski, A., \& Polechoński, J. (2019). Association between objectively measured physical activity and musculoskeletal disorders, and perceived work ability among adult, middle-aged and older women. Clinical interventions in aging, 14, pp.1975-1983.

14. Motamedzade, M., Faghih, M. A., Golmohammadi, R., Faradmal, J., \& Mohammadi, H. (2013). Effects of physical and personal risk factors on sick leave due to musculoskeletal disorders. International journal of occupational safety and ergonomics, 19(4), pp. 513-521.

15. Shah, M. (2017). Role of nutrition in musculoskeletal health. In Non-Pharmacological Management of Osteoporosis (pp. 53-57). Springer, Cham

16. Roquelaure, Y., Ha, C., Rouillon, C., Fouquet, N., Leclerc, A., Descatha, A., Touranchet, A., Goldberg M., Imbernon, E., \& Members of Occupational Health Services of the Pays de la Loire Region. (2009). Risk factors for upper-extremity musculoskeletal disorders in the working population. Arthritis Care \& Research, 61(10), pp. 1425-1434.

17. Micheletti, J. K., Bláfoss, R., Sundstrup, E., Bay, H., Pastre, C. M., \& Andersen, L. L. (2019). Association between lifestyle and musculoskeletal pain: cross-sectional study among 10,000 adults from the general working population. BMC musculoskeletal disorders, 20(1), pp. 1-8.

18. Al-Bashaireh, A. M., Haddad, L. G., Weaver, M., Kelly, D. L., Chengguo, X., \& Yoon, S. (2018). The effect of tobacco smoking on musculoskeletal health: a systematic review. Journal of environmental and public health.

19. Majjad, A., Errahali, Y., Toufik, H., H Djossou, J., Ghassem, M. A., Kasouati, J., \& Maghraoui, A. E. (2018). Musculoskeletal disorders in patients with diabetes mellitus: a cross-sectional study. International journal of rheumatology.

20. Duffield, S. J., Ellis, B. M., Goodson, N., Walker-Bone, K., Conaghan, P. G., Margham, T., \& Loftis, T. (2017). The contribution of musculoskeletal disorders in multimorbidity: implications for practice and policy. Best practice \& research clinical rheumatology, 31(2), pp. 129-144.

21. Horton, M. A. (2019). Human Factors in Dentistry. Primary dental journal, 8(2), pp. 30-33.

22. Wright, S., Ucer, C., \& Speechley, S. (2018). The perceived frequency and impact of adverse events in dentistry. Faculty Dental Journal, 9(1), pp. 14-19.

23. Perrin, P., Eichenberger, M., Neuhaus, K. W., \& Lussi, A. (2016). Visual acuity and magnification devices in dentistry. Swiss dental journal, 126(3), pp. 222-235. 
24. Doppalapudi, N., \& Burugapalli, R. K. (2020). Benefits of Utilization of Magnification in Dentistry: A Review. Dental Research and Oral Health, 3(3), pp. 121-128.

25. Ahearn, D. J., Sanders, M. J., \& Turcotte, C. (2010). Ergonomic design for dental offices. Work, 35(4), pp. 495-503.

26. Magnavita, N., Elovainio, M., De Nardis, I., Heponiemi, T., \& Bergamaschi, A. (2011). Environmental discomfort and musculoskeletal disorders. Occupational medicine, 61(3), pp. 196-201.

27. Schettini, S. R. L., \& Gonçalves, C. G. D. O. (2017). Quality of life, perception and knowledge of dentists on noise. Revista CEFAC, 19(6), pp. 782-791.

28. Khaimook, W., Suksamae, P., Choosong, T., Chayarpham, S., \& Tantisarasart, R. (2014). The prevalence of noise-induced occupational hearing loss in dentistry personnel. Workplace health \& safety, 62(9), pp. 357-360.

29. Chowdhry, R., \& Sethi, V. (2017). Hand arm vibration syndrome in dentistry: A review. Current Medicine Research and Practice, 7(6), pp. 235-239.

\section{METODOLOŠKI OKVIR ZA ISTRAŽIVANJE ERGONOMSKIH FAKTORA RIZIKA U STOMATOLOGIJI}

U ovom radu je predložen metodološki okvir za istraživanje ergonomskih faktora rizika u stomatologiji budući da se radi o profesiji sa vrlo specifičnim i složenim ergonomskim izazovima. Prilikom analize ergonomskih faktora rizika u stomatološkoj praksi treba uzeti u obzir tri odvojene celine: stomatologa, kao centralnu figuru u ordinaciji, stomatološku opremu, koja uključuje sve instrumente $i$ uređaje, stomatološku stolicu i stolicu za stomatologa; $i$ stomatološku ordinaciju, odnosno uredjenost ordinacije $i$ radne uslove u njoj. Pošto je nemoguće potpuno eliminisati rizik, sistematska analiza ergonomskih faktora rizika će omogućiti predlaganje mera za njegovo smanjenje. Smanjenjem rizika postiže se poboljšanje radne sposobnosti stomatologa $i$ radnih uslovi u stomatološkoj ordinaciji, a obezbeđuje se i humaniji, tj. funkcionalniji dizajn opreme koja se koristi.

Ključne reči: ergonomski faktori rizika, metodološki okvir, stomatolog, stomatološka ordinacija 